\title{
Identification of Problem and Measuring the Satisfaction of Customer from Services- An Examination on Hitachi
}

\author{
Nahid Rauf, Md. Moneef Ahmad, Mohd. Junaid Ahmad, Mohd. Ajmal
}

\begin{abstract}
This analysis paper directional to the objectives of understanding the issues related to Hitachi from the dealer's perspective and measure satisfaction of shoppers from the services provided. This involves Associate in the Nursing understanding of issues of shoppers so organize its technologies, products, services and alternative business resources to figure to attain innovation and deliver solutions to those problems. To know the market conditions and customers expect it's necessary to induce to grasp the issues facing the one United Nations agency is facing it and to figure on an equivalent. As my study is on the point of deciding the gaps that area unit directly or indirectly affects the market share of the whole. The study conjointly talks concerning the customer's satisfaction and dealer's perspective towards the whole and also the improvement areas. The aim wasn't solely to search out the problems and improvement areas however to search out the ways that to resolve the problems and to figure for an equivalent. The analysis style used was beta and descriptive style with the assistance of structured questionnaires to know the dealer's perspective and also the customer's perspective. The 2 major gaps found were Service and promoting of product. The problems faced in Services were major relating to the time taken to unravel issues that makes the client disgruntled. In promoting, major concern space is relating to the GTM (Go to market) team which incorporates MO (Merchandising officers) no correct visits to stores and dealer's discontent relating to their irregular visits and handling of problems by them. alternative problems were the distribution of POS (Point of sale) materials not on correct time and HPC's (Hitachi profile communicators) information problems relating to the merchandise For services, the main areas to figure on installation and replacement problems The strategies to figure on the development areas are: ought to work on the KRA's (Key responsibility areas) for MO's to figure for the merchandise coaching of HPC's to attach with the shoppers through layman's terms ACC.
\end{abstract}

Keywords: Consumer durables, Service aspects, chi-square, cross-tabulation, Dealers prospective.

Revised Manuscript Received on November 22, 2019.

* Correspondence Author

Nahid Rauf, Assistant Professor in Prince Sattam Bin Abdul Aziz University, Al-Kharj, Kingdom of Saudi Arabia. Email: nahidanam28@gmail.com.

Md. Moneef Ahmad, Research Scholar, Department of Commerce, AMU, Aligarh, Email: munif.ahmad1234@gmail.com.

Mohd. Junaid Ahmad, Director, Cynna India Pvt. Ltd., Noida, Email: junaidahmad487@gmail.com, junaid@netaaji.com.

Mohd. Ajmal, Post Doctoral Fellow (ICSSR), Department of Commerce, AMU, Aligarh; Email: ajmalwaseem@gmail.com.

\section{INTRODUCTION}

The consumer durable industry comprises of durable products and appliances for local utilize, for example, TVs, fridges, air conditioners, and clothes washers. The consumer durables showcase is assessed to be US\$ 15 billion as on May 2017 and is relied upon to reach US\$20.6 billion by 2020 . Urban markets represent the real offer 4 (65 percent) of absolute incomes in the consumer durables part in India There is a great deal of degree for development from country markets with utilization expected to develop in these zones as infiltration of brands increments. Consumer hardware trades from India came to US\$ 186.7 million amid April-September 2017. Likewise, interest for durables like coolers just as consumer electronic products is probably going to observe developing interest in the coming a very long time in the provincial markets as the administration intends to put altogether in country zap. Developing mindfulness, simpler access, and changing ways of life have been the key development drivers for the consumer advertise. The Government of India's strategies and administrative systems, for example, unwinding of permit principles and endorsement of 51 percent Foreign Direct Investment (FDI) in multi-brand and 100 percent in single-brand retail are a portion of the real development drivers for the consumer advertise. India is probably going to rise as the world's biggest white-collar class consumer showcase with a totaled consumer spend of almost US $\$ 13$ trillion by 2030, according to a report by Deloitte titled 'India matters: Winning in development markets'. Fuelled by rising salaries and developing reasonableness, the consumer durables advertise is relied upon to extend at a Compound Annual Growth Rate (CAGR) of 14.8 percent to US\$ 12.5 billion in FY 2015 from US\$ 7.3 billion in FY 2012. Urban markets represent the real offer ( 65 percent) of absolute incomes in the Indian consumer durables segment. In provincial markets, durables, for example, iceboxes, and consumer electronic products are probably going to observe developing interest in the coming years. From US\$ 2.1 billion in FY 2010, the country advertise is relied upon to develop at a CAGR of 25 percent to contact US $\$ 6.4$ billion in FY 2015. Source: JP Morgan, Tech Navio, Spark Capital assessments and EY investigation 5 The Market of white merchandise and TVs has developed since the year 2009. The outline 1 inferred beneath demonstrates the market development over different years for the referenced four merchandise and a projection of development continuously 2020. In the investigation, it is

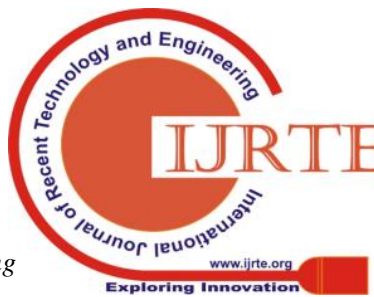




\section{IDENTIFICATION OF PROBLEM AND MEASURING THE SATISFACTION OF CUSTOMER FROM SERVICES- AN EXAMINATION ON HITACHI}

seen that the CAGR between the years 2009 to 2013 was at $13.7 \%$ which expanded to CAGR of $17 \%$ from the year 2013 to the anticipated the year 2020. The all-out market which was INR 403 billion for the four white products including TV has come to a complete market of INR 1077 billion constantly 2016 and is anticipated to reach at INR 2021 billion continuously 2020 . The market entrance for the above merchandise can likewise be contrasted and the worldwide market. In correlation, it tends to be seen Indian durable market is having the capacity to become further. The consumer durables showcase in India is evaluated to have achieved Rs. 1 trillion (US\$ 15.5 billion) in 2017. The consumer durables/light electrical industry is required to achieve Rs. 3 trillion (US\$ 46.54 billion) by 2020. Indian gadgets showcase is required to develop at 41 percent CAGR in 2017-20 to reach US\$ 400 billion. Consumer gadgets sends out from India came to US\$ 385.15 million in FY18 (up to February 2018). India will be one of the main three markets for Johnson Controls-Hitachi Air Conditioning-a joint endeavor between the US-headquartered Johnson Controls Inc. furthermore, Japan's Hitachi Appliances, Inc. - by 2020, its worldwide CEO Franz Cerwinka. At present, India is among the main 10 markets for the organization that was set up in October 2015, representing around $10 \%$ of its income. For the monetary year 2015, Johnson Controls revealed $\$ 37.2$ billion income, of which about $28 \%$ originated from its structure effectiveness unit, $18 \%$ from power arrangements and the staying $54 \%$ from the car experience business. "We would keep on playing in the best end, or premium portion. In any case, we are hoping to tap the business air-molding space, including government ventures, for quicker development. We are hoping to twofold the India advertise throughout the following five years. In any case, I can't unveil the speculation figures," said Cerwinka. As indicated by the worldwide CEO, the organization has about $11 \%$ piece of the overall industry in India which intends to push up to $20 \%$ in the following five years. "We will dispatch more items for the private fragment. Advancement and improvement of the most vitality proficient and condition inviting items will be our key need to set up our image's prosperity and remarkable personality," he included. This season, AC producers are pushing vitality sparing as a USP. New rollouts this year recommend organizations like Godrej Appliances and Videocon Industries Ltd are looking at an offer of the superior market so far ruled by remote brands. In the interim, the industry is anticipating the usage of the Seventh Pay Commission that is relied upon to support development for the business that saw a log jam over the most recent two years. As per a report by rating organization ICRA, the effect of the usage of the compensation commission proposals will result in an utilization increase in about Rs. 61,260 crore or $0.39 \%$ of total national output and family unit funds is evaluated to increment by Rs. 40,840 crores or $0.26 \%$ of GDP.

\section{Research Problem}

The research problem for my project is regarding those gaps which provided me insights regarding the problems which are hindrances in enhancing market share

The research problems are as follows:
1. The reasons for low market share and find out the ways to improve the same.

2. The effect of visibility and marketing on sales of the refrigerator and to find out ways for enhancement.

\section{Research question and Hypothesis}

The hypothesis formed from the major findings of the data analysis done with respect to customer satisfaction with after-sales services are as follows:

1. $\mathrm{H}_{0}$ : There is no relationship between the time taken to solve issues and overall satisfaction

2. $\mathrm{H}_{1}$ : There is a relationship between the time taken to solve the problem and overall satisfaction

3. $\mathrm{H}_{0}$ : There is no relationship between the cost of after-sales service and overall experience

4. $\mathrm{H}_{2}$ : There is a relationship between the cost of after-sales service and overall experience

\section{Objectives of the Research}

The objectives of the project reports are divided into:

1. To know the dealers' perspective towards Hitachi as a brand

2. To know the satisfaction level of customers regarding after-sales-service of Hitachi

5. To understand the KRA of MO's and Promoter's for their training enhancement

\section{REVIEW OF LITERATURE}

Past looks into done by researchers have affirmed that Customer fulfillment assumes an interceding job. Nagarajan. $\mathrm{R}$ and P.Pinakapani - Impact of Retailer Brand Equity on Customer Loyalty and the Mediating Role of Customer Satisfaction (2017); (Krishnan. R 2015) Raaghav R. (2016), uncovered that consumer loyalty intercedes the impact of administration quality on client dedication. Govindaraj G, (2014), affirmed the intervening job of fulfillment on administration quality and Customer faithfulness in the retail banking area. Additionally, Rajalakshmi, (2014) likewise affirmed that there is an interceding job of fulfillment on the connection between the Brand Equity and Customer dependability in Chinese doll industry. In addition, Sai Prasad, M (2008) has additionally affirmed that the impact of administration quality on Customer reliability, intervened by consumer loyalty in the sustenance business. Consumer loyalty is a standout amongst the most broadly looked into points in showcasing (Klee, 1997). For instance, consumer loyalty has been inspected, at the producer level as well as at the retailer-level (Janardhanan, 2015). Be that as it may, similarly fewer investigations have considered the results of consumer loyalty (Yadhav 2011). For instance, it isn't obvious from the present advertising writing whether consumer loyalty is connected to some elusive resources, for example, brand value. Specifically, the linkages between consumer loyalty and retail brand value are not attractively clarified.

As per McIIroy et al (2000) (ref in Lowenstein, 1995) is consumer loyalty an essential idea to think about when building up a client club. Since fulfillment is a proportion of how well a client's desires are met while client steadfastness is a proportion of how likely a client is to repurchase and take

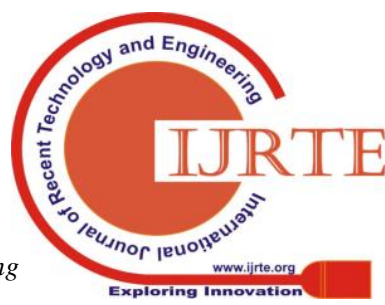


part in related exercises. In any case, it is imperative that organizations know about that a devoted and fulfilled client can in all respects effectively change to a contender on the off chance that they are offered superior esteem or quality. There is no assurance that a fulfilled client will come back to the organization yet it is practically sure that a disappointed client won't return. (Mcllroy et al, 2000). Anderson and Mittal, (2000) says that as per the fulfillment benefit chain standard improving item and administration characteristics cause expanded consumer loyalty, expanded consumer loyalty prompts more noteworthy client maintenance and improved client maintenance more noteworthy productivity. The estimation of consumer loyalty is especially vital in the administrations' area, for example, consumer durable white products. Hoyer and MacInnis (2001) said that fulfillment can be related to sentiments of acknowledgment, bliss, help fervor and pleasure. There are a few dimensions of client: Dissatisfied client Looking for another person to give item or administration, fulfilled client open to the following better chance, faithful client returns notwithstanding offers by the challenge. Hansemark and Albinsson,(2004) express that "fulfillment is a general client frame of mind towards a specialist co-op, or an enthusiastic response to the distinction between what client envision and what they get, with respect to the satisfaction of some need, objective or want". Vance Christensen, (2006), found that consumer loyalty has little to do with client dependability. A fulfilled client will remain until there is a superior option offered to them - regardless of whether their desires are surpassed. Vance Christensen, (2006) uncovers that consumer loyalty is altogether different from client devotion. One is a necessity to work together; the other is the reason for supported productivity and development. Xueming and Christian, (2007), surely concur that consumer loyalty is a focal develop in advertising research. Past examinations showed that fulfillment's impact on dependability's increasingly evident in the clients who are unpracticed with a brand than the individuals who are because of a transformative procedure that drives loyalty.

\section{RESEARCH METHODOLOGY}

Research methodology gives an outline or framework of how the Research is conducted. It guides us in the collection and analysis of the data. This section provides us with the research procedures and methods that are to be adopted for achieving the Project Objectives.

\section{PRIMARY DATA SOURCES:}

In all, we collected information from a sample of 131 store managers and 169 customers. The Data is collected through a self-administrated questionnaire which filled by them in the hard copy of the questionnaire

SECONDARY DATA SOURCES:

Secondary data is collected from various research literature for a similar research question.

\section{RESEARCH DESIGN}

The overall purpose of this project is "To analyze the performance of Hitachi as a brand in the Delhi market and to find out the gaps in order to enhance their performance". I used a descriptive and exploratory design.

\section{SAMPLING}

Since it is not possible to study all Hitachi Customers and all the dealers around Delhi, therefore I took the stores as per the company's preference for my research.

\section{SAMPLING UNITS:}

Customers who have used Hitachi's After Sales Services in the month of April and May 2018 and dealers who are dealing with the brands mainly in refrigerator and AC. SAMPLING TECHNIQUE:

Non-probability Convenience Sampling Method has been used to gather respondents.

\section{SAMPLE SIZE}

The sample size is of 131 for Dealer's perspective and 169 for the customer's after sales service satisfaction

\section{RESEARCH INSTRUMENT}

Structured Questionnaires were developed for getting the responses from the Sample Population.

\section{PROCESSING \& DATA COLLECTION}

PRIMARY DATA is collected from various customers through personal interaction and with the help of interaction with dealers through visits

SECONDARY DATA from the internet, journals, books, magazine etc.

METHOD OF CONTACTING THE RESPONDENTS AND COLLECTION OF DATA:

The door to door visits and telephonic interviews was done to reach my target sample.

\section{STATISTICAL AND ANALYTICAL TECHNIQUES}

The data collected through questionnaires were arranged in various tables and proposed to critical analysis with the help of a few statistical tools like Pearson's Test.

Microsoft Office along with SPSS was used during the project for analyzing the results and preparing graphs, reports \& Questionnaires, which were prepared especially for the survey.

\section{DATA ANALYSIS AND INTERPRETATION}

The analysis is done by the collection of data from Store visits and interaction with the existing customer the help of different tools.

Analysis of HITACHI's Performance on the basis of the dealer's perspectives.

Q1. COMPARATIVE ANALYSIS OF HITACHI's AC WITH COMPETITORS ON THE BASIS OF ASSOCIATING FACTORS:

\begin{tabular}{|c|c|c|}
\hline PREFERENCES & HITACHI & COMPETITORS \\
\hline $\begin{array}{l}\text { QUALITY OF } \\
\text { PRODUCT }\end{array}$ & 49 & 25 \\
\hline $\begin{array}{l}\text { PROMOTIONAL } \\
\text { SCHEMES }\end{array}$ & 14 & 15 \\
\hline PRICING & 8 & 6 \\
\hline SERVICE & 8 & 37 \\
\hline MARGIN & 19 & 21 \\
\hline
\end{tabular}




\begin{tabular}{|l|l|l|}
\hline $\begin{array}{l}\text { COMPANY } \\
\text { POLICY }\end{array}$ & 8 & 6 \\
\hline OTHERS & 25 & 21 \\
\hline
\end{tabular}

ANALYSIS TABLE 7.1

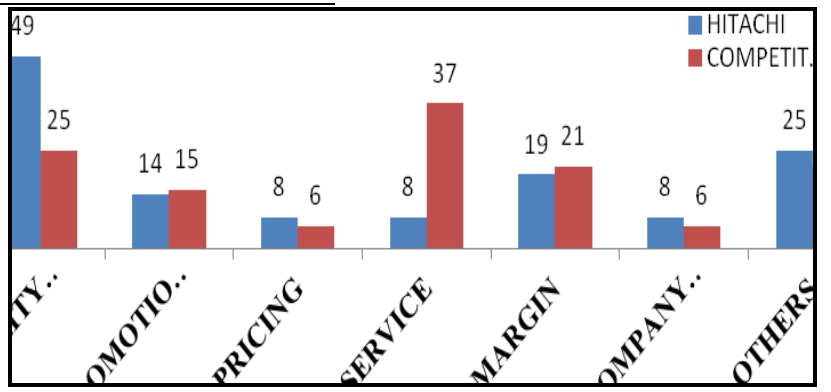

This is visible from the above analysis that service is a major reason for which the dealers like to associate with other brands in spite of Hitachi. On the other hand, the other factors like Quality of product Hitachi are far very better than others.

Q2. COMPARATIVE ANALYSIS OF HITACHI's REFRIGERATOR WITH COMPETITORS ON THE BASIS OF ASSOCIATING FACTORS:

\begin{tabular}{|l|l|l|}
\hline PREFERENCES & $\begin{array}{l}\text { HITACH } \\
\text { I }\end{array}$ & $\begin{array}{l}\text { COMPETITOR } \\
\text { S }\end{array}$ \\
\hline $\begin{array}{l}\text { QUALITY OF } \\
\text { PRODUCT }\end{array}$ & 35 & 23 \\
\hline
\end{tabular}

\begin{tabular}{|l|l|l|l|}
\hline PREFERENCES & FREQUENCY & PERCENTAGE & $\begin{array}{l}\text { CUMULATIVE } \\
\text { PERCENTAGE }\end{array}$ \\
\hline MARKETING & 40 & 30.50 & 30.50 \\
\hline SERVICES & 52 & 39.69 & 70.69 \\
\hline SALES & 6 & 04.58 & 74.77 \\
\hline LOGISTICS & 13 & 09.92 & 84.69 \\
\hline COMMERCIAL & 14 & 10.68 & 95.37 \\
\hline OTHERS & 6 & 04.58 & 100.0 \\
\hline TOTAL & 131 & 100.0 & \\
\hline
\end{tabular}

Analysis Table 7.3

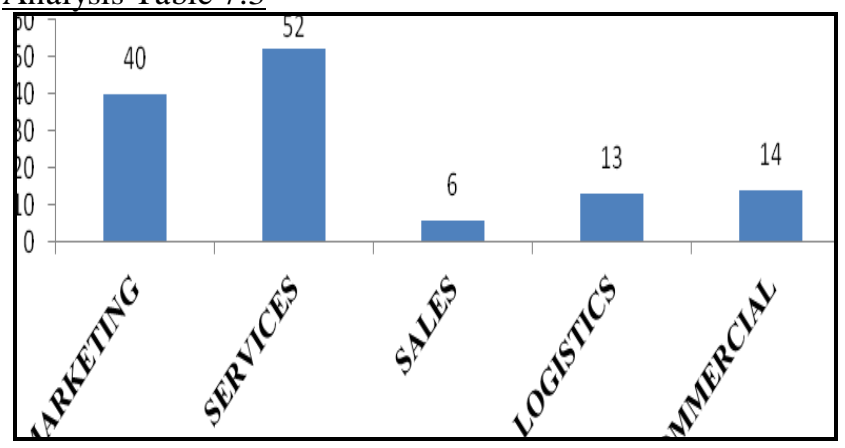

The major concern areas from dealer's perspective are service and marketing which comprises of gaps that are responsible for the loss in the market and even the relationships were not good because of the problems dealers facing due to these factors.

\section{Q4HOW FREQUENTLY DO COMPANY'S MO/ASM VISIT YOUR STORE?}

ANALYSIS TABLE 7.2 cut to cut competition in pricing ISSUE?

\begin{tabular}{|l|l|l|}
\hline $\begin{array}{l}\text { PROMOTIONAL } \\
\text { SCHEMES }\end{array}$ & 15 & 20 \\
\hline PRICING & 5 & 4 \\
\hline SERVICE & 25 & 36 \\
\hline MARGIN & 10 & 6 \\
\hline $\begin{array}{l}\text { COMPANY } \\
\text { POLICY }\end{array}$ & 20 & 25 \\
\hline OTHERS & 21 & 17 \\
\hline
\end{tabular}

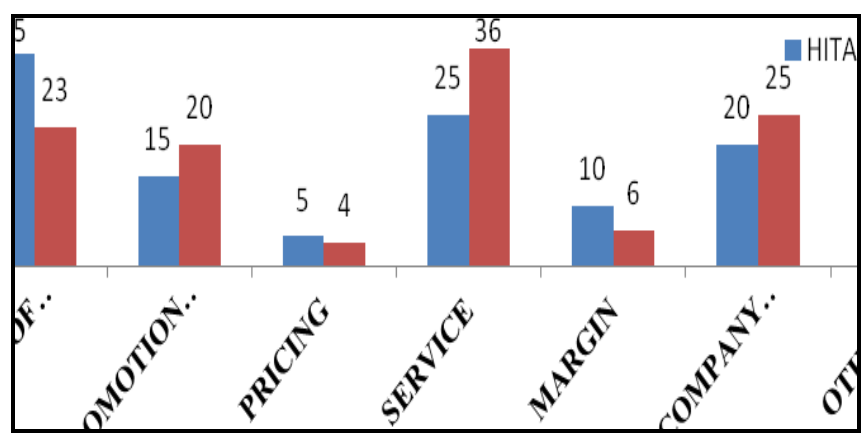

This is interpreted from the above analysis that service is not a very major concern of not associating with Hitachi in case of the refrigeratoras it was in AC. In case of Pricing, there is

Q3. WHICH IS THE MAJOR CONCERN AREA OF

\begin{tabular}{|c|c|c|c|}
\hline $\begin{array}{c}\text { PREFERE } \\
\text { NCES }\end{array}$ & $\begin{array}{c}\text { FREQU } \\
\text { ENCY }\end{array}$ & $\begin{array}{c}\text { PERC } \\
\text { ENTA } \\
\text { GE }\end{array}$ & $\begin{array}{c}\text { CUMULA } \\
\text { TIVE } \\
\text { FREQUEN } \\
\text { CY }\end{array}$ \\
\hline $\begin{array}{c}\text { ONCE A } \\
\text { MONTH }\end{array}$ & 47 & 35.87 & 35.87 \\
\hline $\begin{array}{c}\text { TWICE A } \\
\text { MONTH }\end{array}$ & 33 & 25.19 & 61.06 \\
\hline $\begin{array}{c}\text { THRICE A } \\
\text { MONTH }\end{array}$ & 20 & 15.26 & 76.32 \\
\hline WEEKLY & 31 & 23.66 & 100 \\
\hline TOTAL & 131 & 100 & \\
\hline
\end{tabular}


Analysis Table 7.4

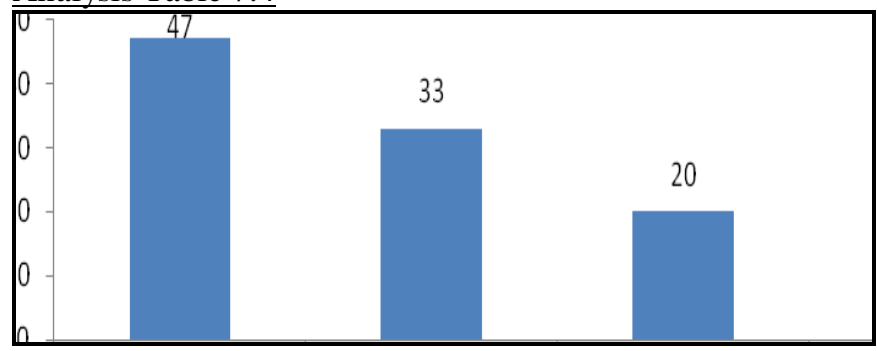

This analysis helped to understand the outcomings which Hitachi is facing regarding their visibility and availability of marketing elements in the stores. As 47 stores reported that the visits are as few as once in a month which is not enough to address their problems and even the availability of the marketing elements in the stores for products and even the training to the promoters is not properly conducted due to these less number of visits.

Q5. RATE YOUR INTERACTION WITH OUR MO.

\begin{tabular}{|c|c|c|c|}
\hline $\begin{array}{c}\text { PREFEREN } \\
\text { CES }\end{array}$ & $\begin{array}{c}\text { RATI } \\
\text { NG }\end{array}$ & $\begin{array}{c}\text { PERCEN } \\
\text { TAGE }\end{array}$ & $\begin{array}{c}\text { CUMULATIV } \\
\text { E } \\
\text { FREQUENCY }\end{array}$ \\
\hline WORST & 26 & 19.84 & 19.84 \\
\hline BAD & 36 & 27.48 & 47.32 \\
\hline NEUTRAL & 23 & 17.55 & 64.87 \\
\hline GOOD & 24 & 18.32 & 83.19 \\
\hline BEST & 22 & 16.79 & 100 \\
\hline TOTAL & 131 & 100 & \\
\hline
\end{tabular}

\section{Analysis Table 7.5}

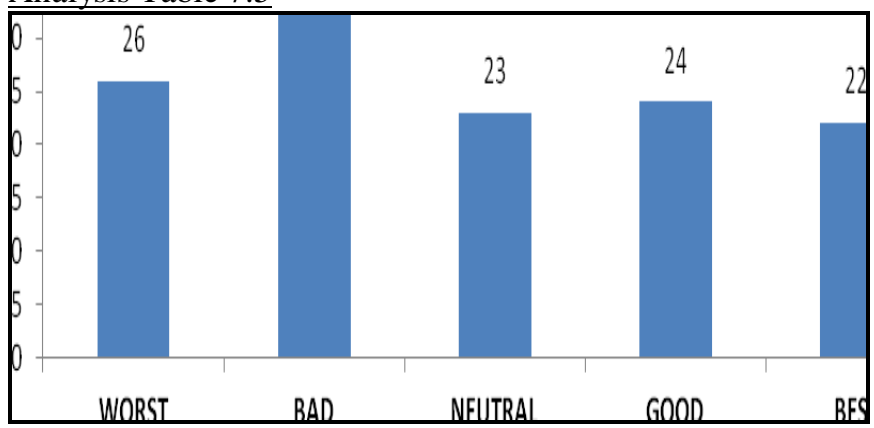

According to above analysis, Best was rated by only 22 stores out of 131 and even the good was rated by 24 which is less than the rating for the bad which is given by 36 stores as there are issues related to visits and for the solving of issues, slow response rate. Therefore the interaction needs to improve that can take place when the visits to the store will increase.

ANALYSIS OF CUSTOMER SATISFACTION REGARDING AFTER SALES SERVICES.

Q1 WERE YOUR CALL TO CUSTOMER CARE EXECUTIVES ACCESSIBLE?

\begin{tabular}{|c|c|c|c|}
\hline $\begin{array}{c}\text { PREFERE } \\
\text { NCES }\end{array}$ & $\begin{array}{c}\text { FREQU } \\
\text { ENCY }\end{array}$ & $\begin{array}{c}\text { PERCEN } \\
\text { TAGE }\end{array}$ & $\begin{array}{c}\text { CUMULATIVE } \\
\text { PERCENTAGE }\end{array}$ \\
\hline YES & 76 & 44.97 & 44.97 \\
\hline NO & 93 & 55.02 & 100 \\
\hline TOTAL & 169 & 100 & \\
\hline
\end{tabular}

Table : Customer Care Accessibility
The very first step taken by the customer whenever they face any issue is to interact with the customer care to resolve the issues as per the data presenting the customers who faced problem to get access to the customer care easily are $55 \%$ which is high from the people who are satisfied with their access to the customer care. It really needs to improve as it creates a bad impression in the minds of the customers which related to bad word of mouth about the brand.

\section{Q2 HOM MANY TIMES YOU HAD TO CALL CUSTOMER CARE TO RESOLVE YOUR CONCERN?}

\begin{tabular}{|l|l|r|l|}
\hline $\begin{array}{l}\text { PREFERENC } \\
\text { ES }\end{array}$ & $\begin{array}{l}\text { No. of } \\
\text { Customer } \\
\text { (FREQUE } \\
\text { NCY) }\end{array}$ & $\begin{array}{l}\text { PERCE } \\
\text { NTAGE }\end{array}$ & $\begin{array}{l}\text { CUMULA } \\
\text { TIVE } \\
\text { FREQUE } \\
\text { NCY }\end{array}$ \\
\hline 1 TIME & 14 & 8.28 & 8.28 \\
\hline 2 TIMES & 2 & 1.18 & 9.46 \\
\hline 3 TIMES & 64 & 37.86 & 47.32 \\
\hline $\begin{array}{l}\text { MORE THAN } \\
\text { 3 TIMES }\end{array}$ & 89 & 52.66 & 100 \\
\hline TOTAL & 169 & 100 & \\
\hline
\end{tabular}

Analysis Table 7.6

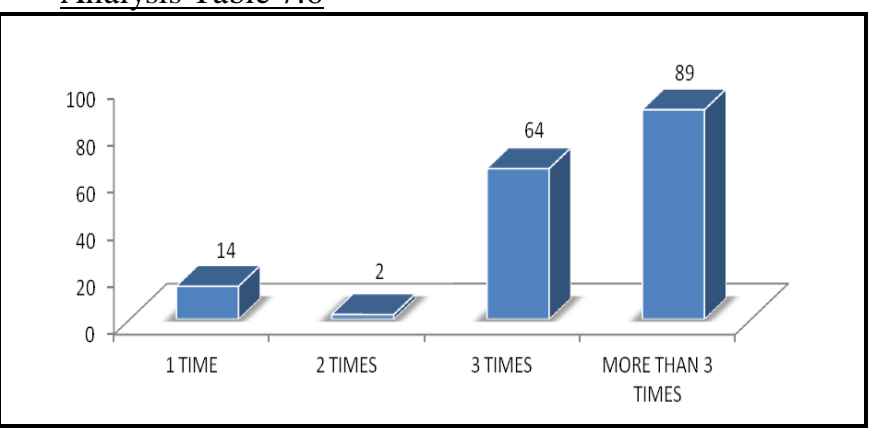

The issues not getting addressed even after calling 3 times and more is a very major issue when we have the neck to neck competitors who are providing well-managed services within the time allotted. This creates a feeling of dissatisfaction in the mind of the customers and which not only affect the sales but also we lose existing customers due to these kinds of problems.

Q3MENTION THE TIME PERIOD YOU HAVE TO

WIAT TO RESOLVE YOUR CONCERN?

\begin{tabular}{|l|l|l|l|}
\hline PREFERENCES & FREQUENCY & PERCENTAGE & $\begin{array}{l}\text { CUMULATIVE } \\
\text { FREQUENCY }\end{array}$ \\
\hline$<24$ Hrs & 36 & 21.3 & 21.3 \\
\hline$<48$ Hrs & 70 & 41.42 & 62.72 \\
\hline$<72$ Hrs & 42 & 24.85 & 87.57 \\
\hline $\begin{array}{l}\text { Still Not } \\
\text { Resolved }\end{array}$ & 21 & 12.42 & 100 \\
\hline TOTAL & 169 & 100 & \\
\hline
\end{tabular}

Analysis Table 7.7 


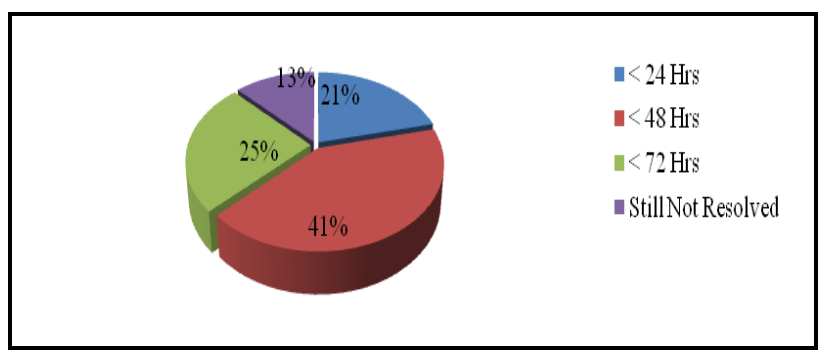

As conveyed by the company's policy, the service issues claim to be resolved in 48 Hours. Still, there are findings which showcase that out of 169 respondent, $25 \%$ are those who say that, it took HITACHI more than 48 Hours and $13 \%$ are those whose concerns are still not resolved.

Q4 MENTION YOUR OPINION ABOUT OVERALL EXPERIENCE OF AFTER SALES SERVICES

\begin{tabular}{|l|l|l|l|}
\hline PREFERENCES & FREQUENCY & PERCENTAGE & $\begin{array}{l}\text { CUMULATIVE } \\
\text { PERCENTAGE }\end{array}$ \\
\hline $\begin{array}{l}\text { Highly } \\
\text { Satisfied }\end{array}$ & 33 & 19.52 & 19.52 \\
\hline Satisfied & 67 & 39.64 & 59.16 \\
\hline Unsatisfied & 69 & 40.82 & 100 \\
\hline TOTAL & 169 & 100 & \\
\hline
\end{tabular}

Analysis Table 7.8

The above factors are major concern areas which are the reason for the dissatisfaction of the customers overall experience. The time taken to resolve the problem majorly falls between $48 \mathrm{hrs}$. To $72 \mathrm{Hrs}$. Which can be one of the major reason for the dissatisfaction of the customers regarding the services provided. As out of 169 customers whose data was analyzed almost $41 \%$ are unsatisfied.

\section{Q5. IS THERE ANY SIGNIFICANT RELATIONSHIP BETWEEN OVERALL SATISFACTION AND TIME TO RESOLVE PROBLEM?}

Observed Frequency

\begin{tabular}{|l|l|}
\hline $\begin{array}{l}\text { Complaint } \\
\text { resolution } \\
\text { time }\end{array}$ & Satisfaction \\
\hline
\end{tabular}

\begin{tabular}{|l|l|l|l|l|} 
& $\begin{array}{l}\text { Highly } \\
\text { Satisfied }\end{array}$ & Satisfied & $\begin{array}{l}\text { Not } \\
\text { satisfied }\end{array}$ & \\
\hline$<24$ & 24 & 10 & 2 & 36 \\
\hline$<48$ & 6 & 28 & 36 & 70 \\
\hline$<72$ & 3 & 12 & 27 & 42 \\
\hline $\begin{array}{l}\text { still not } \\
\text { resolved }\end{array}$ & 0 & 4 & 17 & 21 \\
\hline & 33 & 54 & 82 & 169 \\
\hline
\end{tabular}

\section{Expected Frequency:}

\begin{tabular}{|l|l|l|}
\hline 7.029585799 & $\begin{array}{l}11.5029 \\
6\end{array}$ & 17.46745562 \\
\hline 13.66863905 & $\begin{array}{l}22.3668 \\
6\end{array}$ & 33.96449704 \\
\hline 8.201183432 & 13.4201 & 20.37869822 \\
& 2 & \\
\hline 4.100591716 & $\begin{array}{l}6.71005 \\
9\end{array}$ & 10.18934911 \\
\hline
\end{tabular}

\begin{tabular}{|l|l|}
\hline Test value & $1.1120 \mathrm{E}+00$ \\
\hline Chi square @ 6 df & 1.635 \\
\hline
\end{tabular}

If the test statistic value is greater than with upper tail critical value or less than the lower critical value the null hypothesis will be rejected

In this case, the test, statistics value is less than the lower critical value (1.635@6 df) hence the null hypothesis is rejected. Therefore there is a significant relationship between Time to solve Issues and Overall satisfaction.

\section{Q6. IS THERE A SIGNIFICANT RELATIONSHIP BETWEEN OPINION ABOUT THE COST OF AFTER SALES SERVICES AND OPINION ABOUT OVERALL EXPERIENCE WITH AFTER SALES SERVICES? \\ Dependent Variable: Overall Satisfaction}

Independent Variable: Cost of after sales service

Related Information: Respondents were asked regarding their opinions on the cost and overall satisfaction (1= Highly Satisfied, 2=Satisfied, 3=Dissatisfied)

\begin{tabular}{|c|c|c|c|c|c|}
\hline \multicolumn{6}{|c|}{$\begin{array}{l}\text { Mention your opinion aboutthe cost of after-sales service * Mention your opinion about overall experience with } \\
\text { after sales service } \\
\text { Cross-tabulation }\end{array}$} \\
\hline \multicolumn{6}{|l|}{ Count } \\
\hline & & \multicolumn{3}{|c|}{$\begin{array}{l}\text { mention your opinion about overall experience with after } \\
\text { sales service }\end{array}$} & \multirow[t]{2}{*}{ Total } \\
\hline & & Highly satisfied & Satisfied & Dissatisfied & \\
\hline \multirow{3}{*}{$\begin{array}{l}\text { Mention Your Opinion } \\
\text { About Cost Of After Sales } \\
\text { Service }\end{array}$} & Highly Satisfied & 9 & 13 & 18 & 40 \\
\hline & Satisfied & 9 & 13 & 19 & 41 \\
\hline & Dissatisfied & 15 & 28 & 45 & 88 \\
\hline \multicolumn{2}{|l|}{ Total } & 33 & 54 & 82 & 169 \\
\hline
\end{tabular}

Chi-Square Tests

\begin{tabular}{|l|c|c|c|}
\hline & Value & DF & $\begin{array}{l}\text { Asymp. Sig. } \\
\text { (2-sided) }\end{array}$ \\
\hline $\begin{array}{l}\text { Pearson } \\
\text { Chi-Square }\end{array}$ & $.853^{\mathrm{a}}$ & 4 & .931 \\
\hline Likelihood Ratio & .854 & 4 & .931 \\
\hline $\begin{array}{l}\text { Linear-by-Linear } \\
\text { Association }\end{array}$ & .731 & 1 & .393 \\
\hline N of Valid Cases & 169 & & \\
\hline
\end{tabular}

Conclusion:- $p$ value $(0.93)$ is greater than the level of significance $(\alpha=0.05)$.Hence we accept null hypothesis i.e. There is no significant relationship between overall satisfaction and cost of after sales service. 


\section{RESEARCH FINDINGS}

1. The two major areas which are majorly responsible for the gaps which were found are:

a. After Sales Service: Time taken to resolve issues leads to customer dissatisfaction.

b. Marketing: Less involvement in marketing, low in visibility.

2. Out of 131 dealers, $27.46 \%$ expressed that their interaction with MO's was bad and $19.84 \%$ claim that it was worse. Only $18.32 \%$ claimed that it was good

3. Out of 131 dealers, $35.87 \%$ claimed that MO's visit their stores once a month, $23.66 \%$ told that MO's visit on a weekly basis.

4. Out of 169 customers, $55 \%$ complained that they have issues in accessing to the customer care

5. Out of 169 customers , $24.85 \%$ complained regarding the time taken to resolve the issues in after sales services

6. Acc. to question no. 6, the value of $p>0.05$ (level of significance), therefore there is no significant relationship between the cost of after-sales service and overall satisfaction 7. Customer opinion regarding satisfaction towards After Sales Service, they still having $41 \%$ dissatisfied respondents.

\section{RECOMMENDATIONS}

1. The company should focus and take proper follow up regarding regular visits of ASM/DSO/RSO so that regular checks on the visibility of marketing elements and advertising

2. Training of promoters should be done on the basis of customer segment knowledge and should train with tactics for the better demonstrations of products

3. Finance scheme should be made more competitive to attract the customers

4. Service Engineer should be given a small sticker on which company toll-free no. should be there so that whenever they go to repair any product they stick it and let the customer know about fast and convenient way reaching company.

5. After sales service needs to improve in every aspect to improve the response rate

6. BTL activities can be done in order to promote our brand, this will not cost very much but will enhance the confidence of TPs and the local consumer will be easily attracted.

7. Planogram of refrigerators should be done in such a way that it should have a competitive product

\section{LIMITATIONS}

1. There was a limitation of time as it was difficult to analyze marketing activities effect as there may be many factors which increase sales of any product apart marketing. 2. For customer satisfaction after salesservice, only 169 customers were included because these are those who recently used after sales service.

3. This research was conducted only for chain stores, with a sample size of 131 and 169 (after sales service).

4. Lack of available and/or reliable data - A lack of data or of reliable data limit the scope of my analysis. It was a significant obstacle in finding a trend and a meaningful relationship

5. Customers become over-optimistic sometimes.
6. Some people were not at all co-operative in filling the questionnaire

\section{SCOPE OF THE RESEARCH}

In this survey, I have considered only the chain stores like Vijay Sales, Sargam Electronics etc. This can be further extended to other stores to get more detailed analysis further, this study can be extended to the product categories which will bring in the globalization to the study. Similarly, this study can be further extended to find out any differences due to the different geographical locations (availability of the product, etc.). The period of research can be extended from 2 months to coming 1 year. The successful model can be developed for the brand on the basis of the findings \& conclusion. SSD channel has very high market potential so proper framework needs to be done for enhancing the policy for dealers and customers.

\section{REFERENCES}

1. Bernardi R A (1994), Validating research results when Cronbach 's Alpha is below .70: A Methodological procedure, Educational and Psychological Measurement, 54(3), pp 766-775.

2. Krishnaswami O R, Ranganatham M (2007), Methodology of Research in Social Sciences, Hyderabad: Himalaya Publishing House, pp 338-339.

3. Hair J F, Anderson R E, Tatham R L, Black W C (1998), Multivariate data analysis, 5 ed, New Jersey: Prentice Hall, Inc.

4. AkanshaAnchaliya, EktaChitnis, Ira Bapna, GitanjaliShrivastava (2012), "Job Satisfaction of bank employees - A comparative study of Public and private sector", ed.

5. Ritu Sinha, R.S.Ghosh, Svetlana Tatuskar, ShwetaMaheswari, Ensisage 2020: Emerging Business Practices, pp 86-102.

6. Srivastava (2008), "Changing retail scene in India", International Journal of Retail \& Distribution Management, Vol. 36, No.9, pp 714-721.

7. Sinha Piyush Kumar and Dwarika Prasad Uniyal (2005), "Using Observation Research for Segmenting Shoppers", Journal of Retailing and Consumer Research, Vol. 12, pp. $35-48$.

8. Jain, R. and Bagdare, S. (2009), "Determinants of Customer Experience in New Format Retail Stores", Journal of Marketing \& Communication, Vol 5, No 2, pp 34-44.

9. T. W. Anderson, An Introduction to Multivariate Statistical Analysis, Wiley, New York, 1958.http://www.businessdictionary.com/definition/multivariate analysis.html\#ixzz2dv3rLx2Y.

10. Anderson, E, Mittal,V., 2000, "Strengthening the Satisfaction-Profit Chain", Journal of Service Research, Vol.32, pp.107-121.

11. Andrew Griffiths., 2007,"101 Ways to Really Satisfy Your Customer," Viva Books Private Ltd, India

12. Frederick F Reich held 1996, "The loyalty effect" Boston bani and Company, Harvard Business School Press.

13. Hansemark and Albinson, 2004, "Customer Satisfaction and Retention: The Experiences of Individual Employees, Managing Service Quality”, 14(1), pp. $40-57$.

14. Mcllroy and Barnett, 2000,'Building Customer Relationships Management Applications affect Customer Satisfaction”, Journal of Marketing, 69 (October), pp.201-207.

15. Vance Christensen,2006, “Customer Experience: Customer Satisfaction versus Customer Loyalty", April 10, TMCnet, Amae software

16. Victoria Seitz, Nabil Razzouk, David Michael Wells, 2010, "The Importance of Brand Equity on Purchasing Consumer Durables: An Analysis of Home Air-conditioning systems", Journal of Consumer Marketing, Vol. 27 Issue: 3, pp.236 - 242.

17. YongjuJeong, Yongsung Lee, 2010, "A study on the customer satisfaction and customer loyalty of furniture purchaser in online shop", Asian Journal on Quality, Vol. 11 Issue: 2, pp.146 - 156. 